\title{
Cranial metric, age and isotope analysis of human remains from Huoshiliang, western Gansu, China
}

\author{
John Dodson
}

Institute for Environmental Research, Australian Nuclear Science and Technology Organisation, Lucas Heights, NSW

jdd@ansto.gov.au

\section{Fiona Bertuch}

Australian Nuclear Science and Technology Organisation, Lucas Heights, NSW

\section{Liang Chen}

Northwest University, Xi'an, China

\section{Xiaoqiang Li}

Chinese Academy of Sciences, Xi'an, China

\section{Introduction}

The Chinese provinces of Gansu and Xinjiang are key places for understanding prehistoric exchange between West and East Eurasia. For the past 2000 years, this has been encapsulated in the term 'Silk Road' (which was, in fact, many roads), but goods and ideas have been exchanged across the region for much longer (e.g. Li et al. 2007). In this regard, the well-known existence of the Ürümqi mummies of Xinjiang, which are of Caucasian origin (e.g. Barber 1999), show that they had opportunity to interact with Mongoloid people much earlier.

Detailed examination of the hundreds of archaeological sites in the region has hardly begun and many of these are just places on a map with no further detail described. There are no regional archaeological surveys of Gansu or Xinjiang, as there are for Henan and Shandong 
(e.g. Liu 2004; Underhill et al. 2008) and those site surveys that have been published focus on grave sites and their inclusions, and are not usually independently dated. There are few detailed material studies from non-grave sites and few independent chronologies to put the region into a wider East Asian prehistory context. Much of what has been described, such as the presence of microliths, pottery and bronze artefacts, has been dated on the basis of comparative analyses from elsewhere, most particularly from eastern China. There is no guarantee that such transported timelines necessarily apply beyond where they were established.

Western China has numerous burial sites, and hundreds of human remains and tomb contents have been analysed. For example, more than 500 human skulls have been examined from Yumen (Gansu) and Datong (Qinghai). These are between 3000 and 3600 BP in age. These are consistently Mongoloid and probably indicate there was little if any western Caucasoid incursion this far east at that time (Tan et al. 2005).

Bronze objects in Xinjiang have been found in a number of burial sites that span $3150 \mathrm{BP}$ to 1900 BP. Those that have human remains in the Tarim Basin and northern Xinjiang sites have remains of Caucasoid people. Undecorated pottery from this region spread eastward, and painted pottery probably entered from the east since these are in Xinjiang earlier than elsewhere (Tao 2001). The Xinjiang mummies date back to about $4000 \mathrm{BP}$ and a westward migration of Mongoloid people from Gansu into eastern Xinjiang is thought to have occurred from about $2000 \mathrm{BC}$ (Tao 2001). The Caucasoid people are generally credited with bringing wheat agriculture, new kinds of artefacts, horsemanship, mud-brick building and new religious practices into eastern Asia (Tao 2001; references in Chengwen and Yoshinori 2002).

Here we describe, date and analyse two skulls and an associated sheep bone to provide new data on the possible co-existence of Caucasoid and Mongoloid peoples in western Gansu, and to comment on health and diet.

\section{Huoshiliang study site}

The Huoshiliang archaeological site is at $40^{\circ} 15.6^{\prime} \mathrm{N}$ and $99^{\circ} 18.3^{\prime} \mathrm{E}$ in the Black River valley of western Gansu Province (Figure 1). It occurs as a largely surface scatter of artefacts across several thousand square metres among sand dunes. The cultural sediments are about $1.6 \mathrm{~m}$ in depth in some places. The site has not been systematically excavated.

Evidence of material culture includes macro-fragments of plain and painted pottery, microliths, bone of Bos (cattle) and Ovis (sheep), copper ore, bronze slag and charcoal (Figure 2). Some of this material may be lag deposit from mobile dune sands and the time-depth sequence is not clear.

Fine particles at the site include small particles of charcoal, pottery, bone and cereal seeds. We have radiocarbon dates on five charcoal samples collected over a $1.6 \mathrm{~m}$ depth profile, and these are consistently aged between $3500 \mathrm{BP}$ and $3600 \mathrm{BP}$ (Dodson et al. 2009). In addition, we have a date from a wheat seed, of $3635 \pm 45 \mathrm{BP}$. We interpret the site as a population centre where cropping, animal husbandry and bronze smelting was carried out. We believe that the majority of copper ore for smelting came from the Baishantang mine site, which is located about $100 \mathrm{~km}$ north of Huoshiliang (Dodson et al. 2009). The area is now devoid of trees, but the abundant charcoal indicates the area had significant woodland at the time of occupation.

In the course of examining the site and collecting charcoal for dating in late 2007, two complete skeletons were seen on the sand surface near the Huoshiliang site. The skeletons were eroding out of the shifting sands, and would likely be destroyed as erosion continued. The skulls (Figure 3) were examined in the Department of Archaeology at Northwest University in Xi'an. A premaxilla sheep bone was also analysed. 


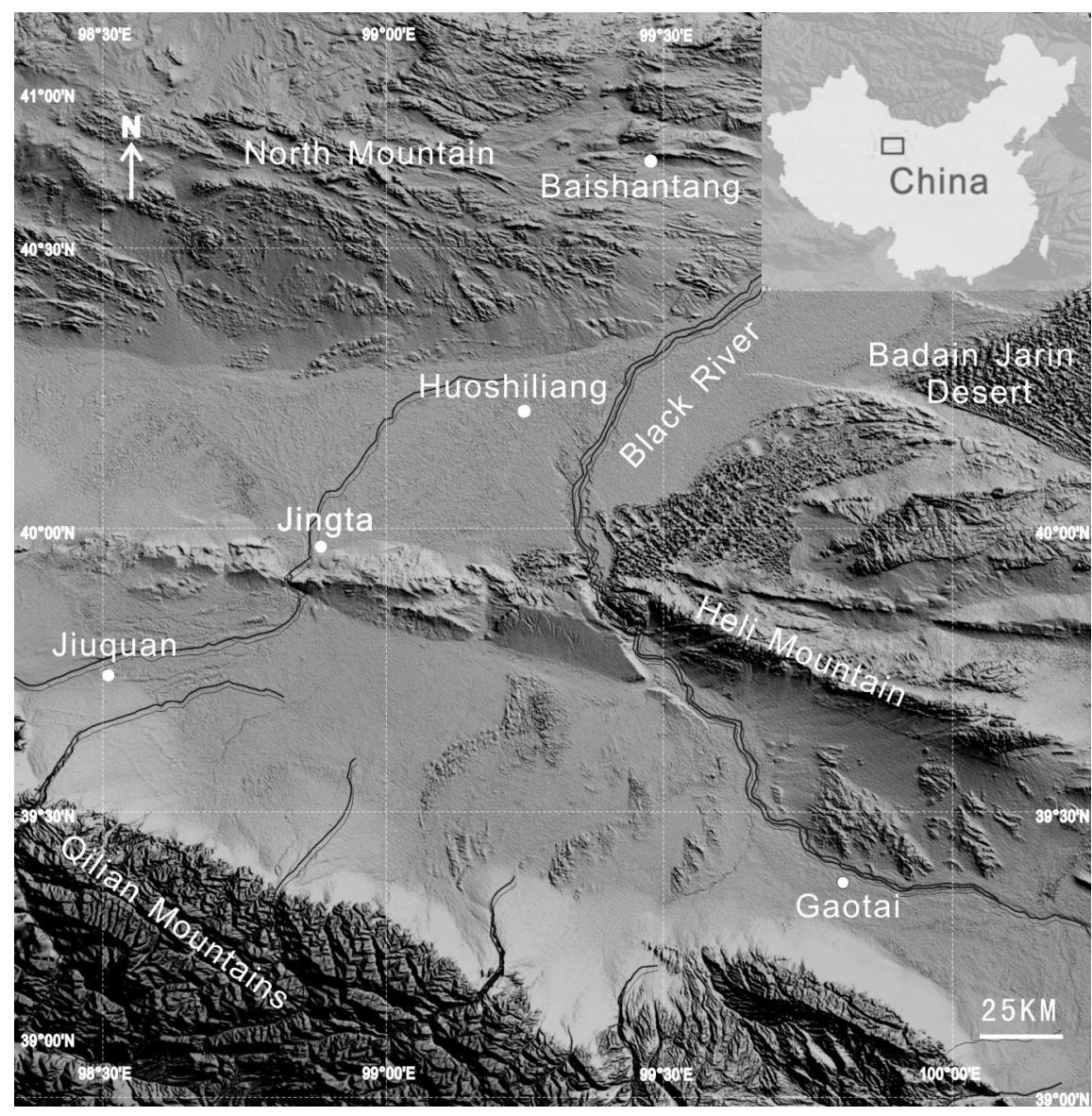

Figure 1. Map of northwestern China showing location of Huoshiliang.

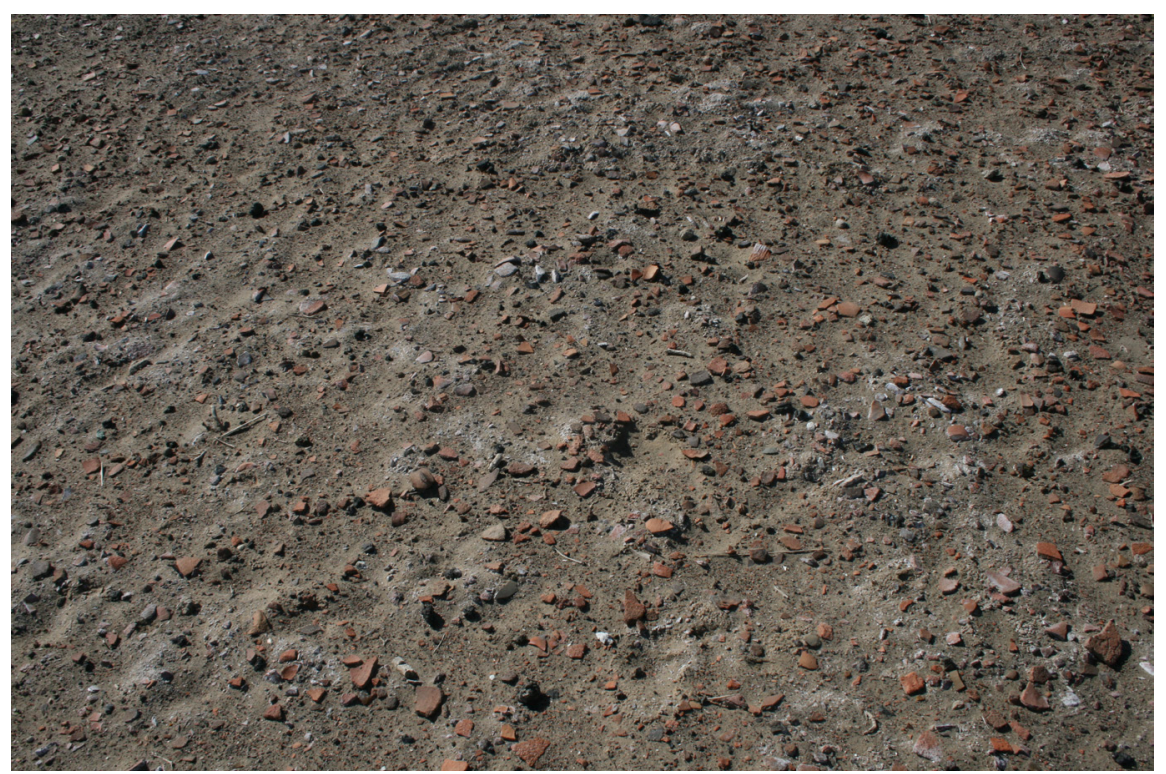

Figure 2. View of site showing scatter of archaeological remains.

\section{Methods}

Using the standard techniques for determining Martin numbers, skull morphological features were measured and described (Martin 1928). Martin numbers are one of several systems for measuring anatomical features and this one was chosen because of its comprehensiveness. Comparative studies were made using the skull collection housed in the Department of Archaeology at North West Normal University in Xi'an and cluster analysis was used to 


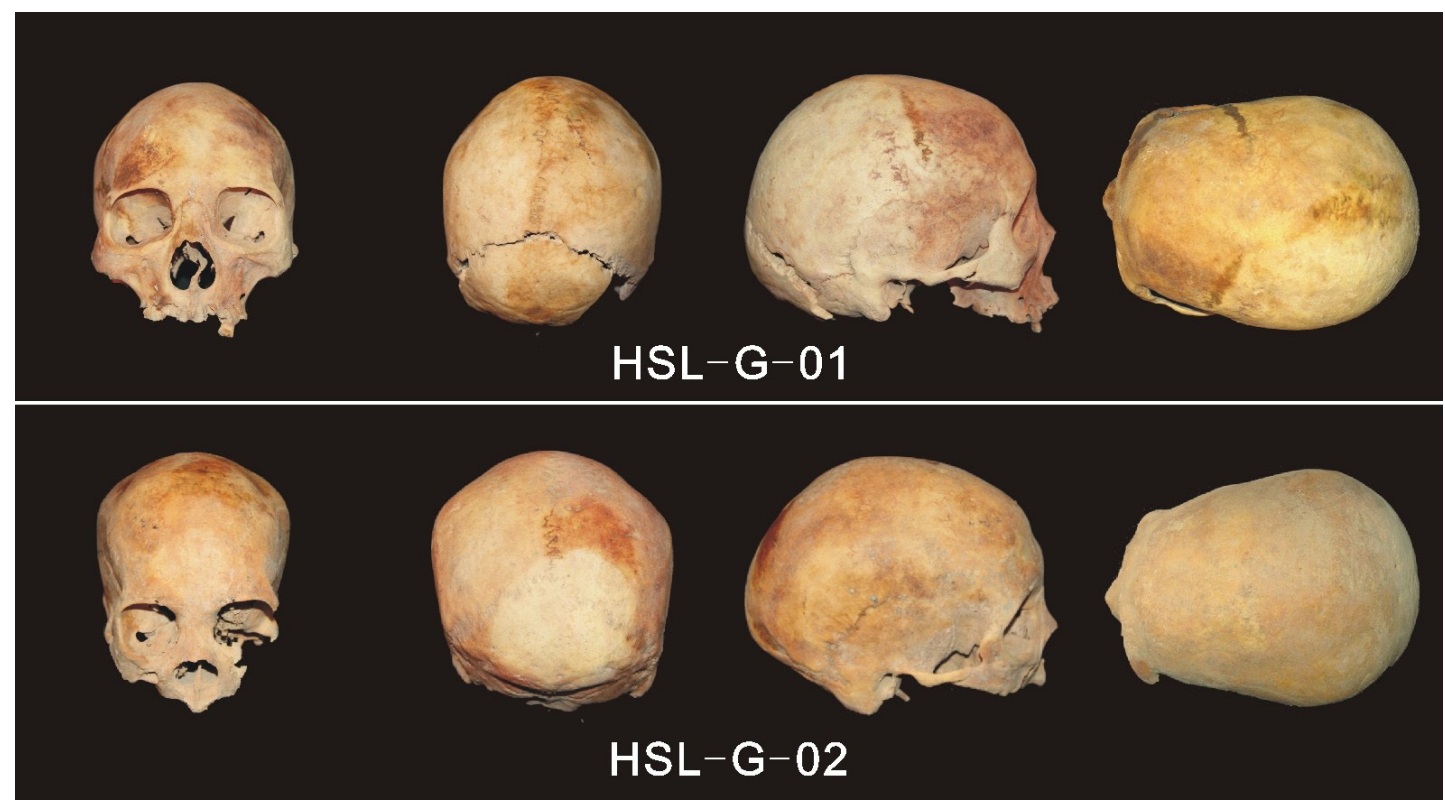

Figure 3. Photograph of skulls from the Huoshiliang archaeological site.

compare these with the Huoshiliang skulls.

About $10 \mathrm{~g}$ of bone from each skull and the sheep bone sample were transported to the Australian Nuclear Science and Technology Organisation (ANSTO) for analysis. The samples were pre-treated for radiocarbon dating in the AMS chemistry laboratories at ANSTO. Collagen was extracted to test whether they showed sufficient preservation and to identify effective removal of contamination to achieve reliable radiocarbon results.

The nitrogen percent of bone, the collagen percent of the sample, and the $\mathrm{C}: \mathrm{N}$ atomic ratio of the extracted collagen were measured. ANSTO uses the ultrafiltration protocol (Brown et al. 1988; Bronk Ramsey et al. 2004; Higham et al. 2006) to pre-treat bone samples for radiocarbon dating. The ultrafiltration method has been shown to remove contamination more effectively than other methods (Bronk Ramsey et al. 2004). Ultrafiltration acts to remove material with a molecular weight below $30 \mathrm{kD}$, which removes contaminants such as salts, fulvic acids and degraded collagen. The main steps in the ultrafiltration protocol used are:

- The bone sample is cleaned with a drill, washed with deionised water, dried and then crushed.

- The crushed bone samples are demineralised with $0.5 \mathrm{M} \mathrm{HCl}$.

- Humics are removed with $0.1 \mathrm{M} \mathrm{NaOH}$.

- Dissolved $\mathrm{CO}_{2}$ is removed with $0.5 \mathrm{M} \mathrm{HCl}$.

- Samples are gelatinised with $\mathrm{pH} 3$ water (heated to $75^{\circ} \mathrm{C}$ for 20 hours).

- Samples are filtered through $100 \mu \mathrm{m}$ polyethylene eezi-filtersTM to remove insoluble residues.

- Eezi-filtered gelatine is then transferred to pre-cleaned Millipore $30 \mathrm{kD}$ ultrafilters and centrifuged until sufficiently filtered.

- The $>30 \mathrm{kD}$ collagen solution is then freeze dried.

- Once the collagen had been extracted, the samples were processed to graphite as described by Hua et al. (2001).

Some problems have been encountered with the ultrafiltration method in the past and have been fully explored in Bronk Ramsey et al. (2004). This contamination originates from the glycerol which is added to the ultrafilter membrane during production. The ultrafiltration 
step in this method only adds carbonaceous contamination to the samples if the filters are not sufficiently cleaned. Quality assurance measures are routine in the ANSTO AMS chemistry laboratories to ensure that the use of ultrafilters does not pose a contamination risk for samples. Tests to ensure all carbonaceous contamination is removed include:

Measuring the quantity of carbon remaining on the ultrafilters after they have been cleaned. To achieve this, an ultrafilter is selected (randomly) for carbon content analysis. No measurable carbon was found, indicating that the ultrafilters had been cleaned satisfactorily.

A bone standard with a known age was run alongside the samples with unknown ages. This sample was selected was one that was a part of the VIRI international laboratory comparison study. The measured age from this bone standard matched the agreed age from the VIRI intercomparison study, and from past measurements that the ANSTO AMS chemistry labs had attained. This further confirms that potential contamination from the use of ultrafilters was negligible.

The glycerol that coats the ultrafilters was also extracted and dated. The glycerol used on the batch of ultrafilters that was used in processing the samples resulted in a date of $1.06 \mathrm{pMC}$ (with an error of \pm 0.0034 ). This suggests no older age offsets, as might be expected if the samples were affected by contamination.

Samples OZL292-OZL294 were measured for $\delta^{13} \mathrm{C}$ and $\delta^{15} \mathrm{~N}$ on a Elemental Analyser (EuroVector EA3000) and an Isotope Ratio Mass Spectrometer (GV Instruments IsoPrime). The reference materials used for the samples were as follows:

- $\delta^{13} \mathrm{C}$ - IAEA C8 oxalic acid with an agreed value of $-18.31 \%$ VPDB (used for graphite, bone and collagen) (Gonfiantini et al. 1995; Le Clercq et al. 2006).

- $\quad \delta^{15} \mathrm{~N}$ - IAEA NO-3 with a consensus value $\mathrm{d}^{15} \mathrm{~N}$ AIR $=+4.7 \%$ (Bohlke and Coplen 1995 ) and IAEA N-2 with a consensus value of $\mathrm{d}^{15} \mathrm{~N}$ AIR $=+20.3 \% 0$ (bone and collagen) (Bohlke and Coplen 1995).

- 3:1 atomic ratio standard - Internal standard of 2-isopropylimidazole (bone and collagen).

- Collagen standard employed: Internal material check standard - un-denatured bovine achilles tendon collagen.

The ${ }^{14} \mathrm{C}$ content was measured on the STAR Accelerator at ANSTO and AMS ages were calculated after estimating fractionation effects from the $\delta^{13} \mathrm{C}$ values determined on the same samples used for dating.

In addition, cereal seeds were collected from the site by sieving surface sands, and we counted a number of these to obtain a snapshot of the types and relative amounts of cereals grown at Huoshiliang.

\section{Results}

Table 1 gives measurements on the two skulls found at Huoshiliang.

\section{Morphological characteristics}

Skull No. 1. The skull is from a middle-aged female, probably between 40 and 45 years of age. Its morphology is oval and the cranial index is 75.64 , meaning it is mesocrany in size. The length-height index of the skull is 74.79 , putting it in the taller metriocrany range. The skull is acrocrany type as the breadth-height index is 98.86 . The middle superscalar arch has a range below $1 / 2$. The forehead is even and straight with a frontal index of 69.7. This places it as eurymetor type, with no suture in the middle forehead. The bregmatic and vertex part in the 
coronal suture are microwave type, and both top and back of the coronal suture are of indented type. The mastoid process is small and the external occipital protuberance is slightly prominent. The orbital cavity is oval (index 73.56), belonging to the lower range in orbital cavity size. The upper part of the Apertura piriformis is heart-shaped, and below this it has a nest type form. The nasal base is superficially hollow, no nasal spine is apparent and the nasal index is 52.38, showing it to be of a broad nasal type. The nasal bridge is hollow type and the nasal bone is Type II. The Canine fossa show moderate growth, the Zygomatic bone is slender (i.e. there is no zygomatic-jaw node) and the jaw angle is clearly evident. Both sides of the skull have Parietal apertures, the sigittal crest is evident and the Palate form is ' $V$ ' type. The Upper facial index is 51.92 , showing it to be meseny type, while the gnathic index is 92.31 , showing it to be orthognath type.

Skull No. 2 The skull is from a female, probably with an age of about 35-40 years. Its morphology is oval and the cranial index is 74.73 , meaning it is a shorter dolichocrany skull type. The middle superscalar arch has a range below $1 / 2$. The forehead is moderate and the frontal index is 66.33 , indicating it is metriometor type. No suture was apparent in the middle forehead. The bregmatic part of the coronal suture is deep wave type. Both the top and back part of the coronal suture are of indented type, while the vertex aperture part is microwave type. The Mastoid process is large and the external occipital protuberance is moderate. The orbital cavity is oval, with an index of 78.65 , suggesting it is medium type. The supraorbital foramen is heart-shaped and its lower edge is obtuse. The nasal base is superficially hollow and the nasal spine is degree II in type. The nasal index is 54.36 and her nose is chamaerrhiny type. The nasal bridge is hollow type and the nasal bone is I type. The Canine fossa is middle range in degree. The zygomatic bone is middle range in height and breadth and no zygomatic-jaw node was apparent. The jaw angle is apparent. Both sides of the skull have Parietal apertures, a sigittal crest is evident, and the Palate form is ' $\mathrm{V}$ ' type.

\section{Interpretation}

The morphology characters of the two skulls are very similar, in being both mesocrany and dolichocrany type. The skulls have simple coronal suture, an oval orbital cavity, medium-narrow

Table 1. Comparative measurements from the Huoshiliang skulls and nine ancient skull groups (female) (mm, degree, \%). The numbers in brackets refer to the sample size for comparative measurements.

\begin{tabular}{|c|c|c|c|c|c|c|c|c|c|c|c|}
\hline $\begin{array}{l}\text { Martin } \\
\#\end{array}$ & Items & HSL & $X C$ & $\mathbf{Q C}$ & PP & SLY & HD & LW & SSJZ (H) & SSJ (K) & LJS \\
\hline 1 & $\begin{array}{l}\text { Cranial } \\
\text { length } \\
(g-0 p)\end{array}$ & $174.49(2)$ & $174.74(5)$ & 173.97 (16) & 177.5 & $180.50(2)$ & $183.9(5)$ & $\begin{array}{l}178.58 \\
(12)\end{array}$ & $174.1(21)$ & $175.1(102)$ & ) 177.30 (8) \\
\hline 8 & $\begin{array}{l}\text { Cranial } \\
\text { breadth } \\
\text { (eu-eu) }\end{array}$ & $134.8(2)$ & $133.26(5)$ & $134.20(16)$ & 140.6 (3) & $137.25(2)$ & $136.1(5)$ & $132.27(10)$ & ) $135.8(21)$ & 135.1 (103) & 136.40 (8) \\
\hline 17 & $\begin{array}{l}\text { Cranial } \\
\text { height } \\
\text { (ba-b) }\end{array}$ & $130.5(1)$ & 137.98 (5) & $135.95(15)$ & 130.6 (3) & $138.50(1)$ & 149.1 (1) & 131.63 (16) & $129.1(18)$ & 131.3 (99) & $130.60(8)$ \\
\hline 9 & $\begin{array}{l}\text { Minimum } \\
\text { frontal } \\
\text { breadth }\end{array}$ & $91.6(2)$ & $86.26(5)$ & 89.89 (17) & 90.7 (3) & $90.47(3)$ & $91.1(5)$ & $87.42(12)$ & $89.0(22)$ & $88.9(102)$ & $89.20(8)$ \\
\hline 45 & $\begin{array}{l}\text { Zygomatic } \\
\text { breadth } \\
\text { (zy-zy) }\end{array}$ & 125.0 (1) & $127.55(2)$ & $127.50(12)$ & $134.0(3)$ & $127.75(2)$ & $134.1(3)$ & $129.04(16)$ & 129.6 (17) & 126.3 & $125.30(7)$ \\
\hline 48 & $\begin{array}{l}\text { Upper facial } \\
\text { height } \\
\text { (sd) }\end{array}$ & $67.8(2)$ & $69.88(2)$ & 67.70 (17) & $67.5(2)$ & $70.70(2)$ & $70.6(4)$ & 70.73 (16) & 71.0 (19) & $71.7(84)$ & 72.10 (8) \\
\hline
\end{tabular}


Table 1. Continued

\begin{tabular}{|c|c|c|c|c|c|c|c|c|c|c|c|}
\hline $\begin{array}{l}\text { Martin } \\
\#\end{array}$ & Items & HSL & $X C$ & $\mathbf{Q C}$ & PP & SLY & HD & LW & SSJZ (H) & SSJ (K) & LJS \\
\hline 52 & $\begin{array}{l}\text { Orbital } \\
\text { height right }\end{array}$ & $33.5(2)$ & $32.38(4)$ & 32.71 (17) & $33.1(3)$ & $31.90(2)$ & $33.4(4)$ & 33.13 (16) & $34.6(22)$ & $34.1(102)$ & $34.60(8)$ \\
\hline 51 & $\begin{array}{l}\text { Orbital } \\
\text { breadth } \\
\text { right }\end{array}$ & $44.0(2)$ & 39.45 (4) & 42.31 (17) & $43.2(3)$ & $40.20(2)$ & $42.2(4)$ & $41.80(16)$ & $40.5(21)$ & 41.0 (103) & 40.90 (8) \\
\hline 54 & $\begin{array}{l}\text { Nasal } \\
\text { breadth }\end{array}$ & $28.1(2)$ & $25.23(4)$ & $26.03(17)$ & $26.5(3)$ & $27.90(2)$ & $27.8(4)$ & $25.76(17)$ & $26.2(20)$ & 25.9 (99) & $26.80(8)$ \\
\hline 55 & $\begin{array}{l}\text { Nasal height } \\
\text { (n-ns) }\end{array}$ & $52.7(2)$ & $50.32(5)$ & 48.75 (17) & $50.0(3)$ & $52.50(2)$ & $50.6(4)$ & $51.03(16)$ & $52.1(21)$ & $52.6(98)$ & $52.40(8)$ \\
\hline 72 & Facial angle & $90.5(2)$ & $81.40(4)$ & 83.27 (15) & 85.7 (3) & 82.00 (1) & 85.7 (3) & 87.00 (12) & $85.4(18)$ & $84.9(76)$ & 86.90 (8) \\
\hline
\end{tabular}

orbital type, an obtuse low edge of the supraorbital foramen, a shallow hollow of the nasal bases and obvious chamaerrhiny. The angle of jaws is down in gradient. They are of moderate range in their Canine fossa, and have hollow-type nasal bridges, evident sigittal crests, meseny and relatively flat degree faces. The two skulls therefore belong to the Mongoloid race.

To further examine their possible origin, an analysis of mean categories for the two cases against mean values for nine ancient groups was carried out. Ten measured items and eight indices and angles from nine ancient groups were selected for the comparison and these are shown in Table 1. In the analysis below, all measurements are based on female skulls, and the nine ancient people groups chosen for comparison are as follows:

(a) Zhou Dynasty people at Xicun in the south of Fengxiang, Shaanxi Province. These skulls are close to South and East Asia types of the Mongolian race.

(b) West Zhou skulls from Wotianma-Qucun in Shanxi Province. The skulls of the group are similar to the East Asia type, but include some factors close to North and South Asia Mongoloid types.

(c) Pengpu Bronze Age people in Guyuan County, Ningxia Province. This skull group belongs to the North Asia Mongoloid type.

(d) A group from the Zhou Dynasty in Shaolingyuan in Xi'an, Shaanxi Province. The skulls of the group are close to South Asia and East Asia types of the Mongolian race, and hence similar to the Xicun group.

(e) The skull group of Neolithic Hedang people in Foushan City, Guangdong Province. The skulls of the group are of South Asia type.

(f) The skull groups of Liuwan, Machang and Qijia cultures in Ledu, Qinghai Province. The skulls of these people are East Asia type.

(g) The skull group from the Han Dynasty in Shangsunjiazhai in Datong, Qinghai Province.

(h) The skull group from the Kayue culture group in Shangsunjiazhai (Datong), Qinghai Province. 
(i) Skull group sample from the of Kayue Culture in Lijiashan, Xunhua, Qinghai Province.

The latter three skull groups are close to the East Asia type of the Mongoloid race and similar to modern Tibetan people.

The comparative data used for analysis are shown in Table 2. The $\mathrm{Dij}$ value between the two skulls from Huoshiliang and nine ancient groups was calculated using the following formula:

Where $i, j$ indicating skull groups, $k$ indicating measured items, $m$ indicating the sample number for measured items. The smaller of $D_{i j}$ value, the closer the morphological set of

$$
D_{i j}=\sqrt{\frac{\sum_{k=1}^{m}(x i k-x j k)^{2}}{m}}
$$

relationships of the skull groups. The results are shown in Table 3. The $D i j$ values show that the skulls of Huoshiliang are most similar to the group of skulls from Liuwan, but differ from the Hedang group and are quite different from the Xicun group of the Zhou Dynasty.

A cluster analysis based on squared Euclidian distances was used to show the distribution of $\mathrm{D} i j$ values between the Huoshiliang group and other groups. The results are shown in Figure 4. This suggests that the Hedang group (6) has greater differences from all other groups, and Pengpu (4) is also relatively different from the other groups. The other eight groups are divided into two categories; with groups 8,9,10, 7, 1 as a category, and group 2, 3, 5 as the other. Morphological character is relatively similar in the group containing 8, 9 and 10. Group 1 belongs to this category and indicates that the Huoshiliang people group are members of the East Asia race. They thus have a close relationship with modern residents in North China. Group 2, 3, 5 is a mixture of South and East Asia Mongoloid people. So the values of Dij and CA analysis all show that the morphology of female skulls in Huoshiliang group is close to the East Asia type of the Mongoloid race.

Table 4 shows the bone protein yield, $\delta^{13} \mathrm{C}, \delta{ }^{15} \mathrm{~N}, \mathrm{C}: \mathrm{N}$ ratio and radiocarbon results. The chemical indicators from the pre-treatments confirmed that the collagen that was extracted

Table 2. The key measurement data of skulls No. 1 and No. 2 from Huoshiliang site.

\begin{tabular}{|c|c|c|c|c|c|c|}
\hline Martin No. & Measured Items & $\begin{array}{l}\text { Skull } \\
1(\wp)\end{array}$ & $\begin{array}{l}\text { Skull } \\
2(+)\end{array}$ & Average & Examples & $\begin{array}{l}\text { Standard } \\
\text { error }\end{array}$ \\
\hline 1 & $\begin{array}{l}\text { Cranial length } \\
(g-0 p)\end{array}$ & 174.5 & 184.0 & 179.25 & 2 & 6.72 \\
\hline 8 & $\begin{array}{l}\text { Cranial breadth } \\
\text { (eu-eu) }\end{array}$ & 132.0 & 137.5 & 134.75 & 2 & 3.89 \\
\hline 17 & $\begin{array}{l}\text { Cranial height } \\
\text { (b-ba) }\end{array}$ & 130.5 & - & 130.5 & 1 & - \\
\hline 21 & uricular height (po-po) & 110.8 & - & 110.8 & 1 & - \\
\hline 9 & Frontal breadth (ft-ft) & 92.0 & 91.2 & 91.6 & 2 & 0.57 \\
\hline 7 & Foramen magnum length (ba-0) & 31.0 & - & 31.0 & 1 & - \\
\hline 16 & $\begin{array}{l}\text { Foramen meanum breadth (FOR. MA. } \\
\text { B) }\end{array}$ & 24.5 & - & 24.5 & 1 & - \\
\hline 25 & Cranial sagittal arc (n-0) & 367.0 & 365.0 & 366.0 & 2 & 1.41 \\
\hline 26 & Nasion-bregma chord (n-b) & 122.0 & 107.0 & 114.5 & 2 & 10.61 \\
\hline 27 & Bregma-lambda chord (b-l) & 132.0 & 142.0 & 137.0 & 2 & 7.07 \\
\hline 28 & Lambda -opisthion chord (I-0) & 113.0 & 116.0 & 114.5 & 2 & 2.12 \\
\hline 29 & Nasion-bregma chord (n-b) & 105.5 & 97.5 & 101.5 & 2 & 5.66 \\
\hline 30 & Bregma-lambda chord (b-l) & 118.0 & 129.8 & 123.9 & 2 & 8.34 \\
\hline
\end{tabular}


Table 2. Continued

\begin{tabular}{|c|c|c|c|c|c|c|}
\hline Martin No. & Measured Items & $\begin{array}{l}\text { Skull } \\
1(†)\end{array}$ & $\begin{array}{l}\text { Skull } \\
2(\%)\end{array}$ & Average & Examples & $\begin{array}{l}\text { Standard } \\
\text { error }\end{array}$ \\
\hline 31 & Lambda -opisthion chord (I-0) & 91.0 & 99.6 & 95.3 & 2 & 6.08 \\
\hline 23 & Cranial horizontal circumference (g,op) & 500.0 & - & 500.0 & 1 & - \\
\hline 24 & $\begin{array}{l}\text { Cranial transverse } \\
\text { arc }(p o-b-p 0)\end{array}$ & 307.0 & - & 307.0 & 1 & - \\
\hline 5 & Basion-nasion length (n-enba) & 97.4 & - & 97.4 & 1 & - \\
\hline 40 & $\begin{array}{l}\text { prosthion to } \\
\text { Endobasion length (pr-enba) }\end{array}$ & 90.0 & - & 90.0 & 1 & - \\
\hline 48 & Upper facial height (n-pr) & 65.7 & 65.0 & 65.4 & 2 & 0.49 \\
\hline 48 & Upper facial height (n-sd) & 67.8 & 67.7 & 67.8 & 2 & 0.07 \\
\hline 45 & $\begin{array}{l}\text { Bijugal breadth } \\
\text { (Facial breadth) (zy-zy) }\end{array}$ & 125.0 & - & 125.0 & 1 & - \\
\hline \multirow[t]{4}{*}{46} & Bimaxillary breadth (zm-zm) & 98.0 & - & 98.0 & 1 & - \\
\hline & sub zm-ss-zm & 25.0 & - & 25.0 & 1 & - \\
\hline & Bimaxillary breadth (zm-zm) & 97.2 & - & 97.2 & 1 & - \\
\hline & sub $z m_{1}-s s-z m_{1}$ & 23.0 & - & 23.0 & 1 & - \\
\hline $43(1)$ & Bifrontal breadth (fmt-fmt) & 103.2 & 105.0 & 104.1 & 2 & 1.27 \\
\hline 50 & Vordere Interorbital breite (mf-mf) & 17.6 & 19.0 & 18.3 & 2 & 0.99 \\
\hline MH L & Zygomatic height left (fmo-zm) & 42.0 & - & 42.0 & 1 & - \\
\hline MH R & Zygomatic height right & 41.8 & 42.3 & 42.1 & 2 & 0.35 \\
\hline MB L & Zygomatic breadth left (zm-rim) & 20.8 & - & 20.8 & 1 & - \\
\hline MB R & Zygomatic breadth right & 22.6 & 25.0 & 23.8 & 2 & 1.70 \\
\hline 54 & Nasal breadth & 27.5 & 28.7 & 28.1 & 2 & 0.85 \\
\hline 55 & Nasal height (n-ns) & 52.5 & 52.8 & 52.7 & 2 & 0.21 \\
\hline SC & Simotic chord & 11.0 & 8.0 & 9.5 & 2 & 2.12 \\
\hline SS & Simotic subtense & 2.2 & 2.6 & 2.4 & 2 & 0.28 \\
\hline $51 \mathrm{~L}$ & Orbital breadth left (mf-ek) & 43.5 & - & 43.5 & 1 & - \\
\hline $51 \mathrm{R}$ & Orbital breadth right & 43.5 & 44.5 & 44.0 & 2 & 0.71 \\
\hline 51a L & Orbital breadth left (d-ek) & 40.6 & - & 40.6 & 1 & - \\
\hline 51a R & Orbital breadth right & 40.5 & 42.4 & 41.5 & 2 & 1.34 \\
\hline $52 \mathrm{~L}$ & Orbital breadth height left & 34.2 & - & 34.2 & 1 & - \\
\hline $52 \mathrm{R}$ & Orbital breadth height right & 32.0 & 35.0 & 33.5 & 2 & 2.12 \\
\hline 03 & Interorbital breadth & 55.0 & - & 55.0 & 1 & - \\
\hline SR & Rhinion height & 12.2 & - & 12.2 & 1 & - \\
\hline 60 & Maxillo-alvaolar length (pr-alv) & 50.0 & 43.0 & 46.5 & 2 & 4.95 \\
\hline 61 & Maxillo-alveolar breadth (ekm-ekm) & 61.8 & 54.0 & 57.9 & 2 & 5.52 \\
\hline 62 & Palatal length (ol-sta) & 44.9 & 42.6 & 43.8 & 2 & 1.63 \\
\hline 63 & Palatal breadth (enm-enm) & 36.3 & 38.6 & 37.5 & 2 & 1.63 \\
\hline \multirow[t]{2}{*}{12} & $\begin{array}{l}\text { Maximum Biasterionic breadth (ast- } \\
\text { ast) }\end{array}$ & 103.8 & 115.2 & 109.5 & 2 & 8.06 \\
\hline & $(p o-p o)$ & 112.6 & - & 112.6 & 1 & - \\
\hline 11 & Biauricular breadth (au-au) & 116.0 & - & 116.0 & 1 & - \\
\hline 44 & Biorbital breadth (ek-ek) & 100.0 & - & 100.0 & 1 & - \\
\hline $\mathrm{FC}$ & $\begin{array}{l}\text { Innere } \\
\text { Biorbitalbreite (fmo-fmo) }\end{array}$ & 95.7 & 100.0 & 97.9 & 2 & 3.04 \\
\hline FS & $\begin{array}{l}\text { Nasal orbital internal } \\
\text { breadth and height }\end{array}$ & 11.2 & 17.5 & 14.4 & 2 & 4.45 \\
\hline DC & Interorbital breadth $(d-d)$ & 20.8 & 21.5 & 21.2 & 2 & 0.49 \\
\hline DN & Dacryon-nasion salient & 3.5 & 5.8 & 4.7 & 2 & 1.63 \\
\hline DS & Dacryal subtense & 6.5 & 7.3 & 6.9 & 2 & 0.57 \\
\hline NLO & Nasal bone length (n-rhi) & 25.8 & 29.0 & 27.4 & 2 & 2.26 \\
\hline RP & Rhinion- Alveolar length (rhi-pr) & 40.4 & 37.0 & 38.7 & 2 & 2.40 \\
\hline
\end{tabular}


Table 2. Continued

\begin{tabular}{|c|c|c|c|c|c|c|}
\hline Martin No. & Measured Items & $\begin{array}{l}\text { Skull } \\
1(\wp)\end{array}$ & $\begin{array}{l}\text { Skull } \\
2(†)\end{array}$ & Average & Examples & $\begin{array}{l}\text { Standard } \\
\text { error }\end{array}$ \\
\hline \multirow[t]{3}{*}{32} & $\begin{array}{l}\text { Profile angle of the frontal bone from } \\
\text { nasion }(\angle n-m F H)\end{array}$ & 86.0 & 82.0 & 84.0 & 2 & 2.83 \\
\hline & $\begin{array}{l}\text { Profile angle of the frontal bone from } \\
\text { glabella }(\angle g-m \text { FH) }\end{array}$ & 81.0 & 77.0 & 79.0 & 2 & 2.83 \\
\hline & Bregmatic angle ( $\angle g-b$ FH $)$ & 46.0 & 47.0 & 46.5 & 2 & 0.71 \\
\hline 72 & Total facial angle ( $\angle n-p r ~ F H)$ & 89.0 & 92.0 & 90.5 & 2 & 2.12 \\
\hline 73 & Nasal prognathism ( $\angle \mathrm{n}-\mathrm{ns} \mathrm{FH})$ & 91.0 & 94.0 & 92.5 & 2 & 2.12 \\
\hline 74 & Alveolar Рrognathism ( $\angle \mathrm{ns}$-pr FH) & 76.0 & 80.0 & 78.0 & 2 & 2.83 \\
\hline 75 & $\begin{array}{l}\text { profilwinkel } \\
\text { des Nasendaches } \\
\text { ( } \angle \text { n-rhi FH) }\end{array}$ & 70.0 & 75.0 & 72.5 & 2 & 3.54 \\
\hline 77 & $\begin{array}{l}\text { Naso-malar angle } \\
(\angle \mathrm{fmo} 0-\mathrm{n} \text {-fmo })\end{array}$ & 154.0 & 143.0 & 148.5 & 2 & 7.78 \\
\hline SSA & Zyyo-maxillary angle ( $\angle$ zm-ss-zm) & 125.0 & - & 125.0 & 1 & - \\
\hline \multirow[t]{5}{*}{ SSA } & $\angle z m 1-s s-z m 1$ & 129.0 & - & 129.0 & 1 & - \\
\hline & $\begin{array}{l}\text { Winkel } \\
\text { des gesichsdreiecks } \\
\text { I ( } \angle n \text {-pr-ba) }\end{array}$ & 76.0 & - & 76.0 & 1 & - \\
\hline & $\begin{array}{l}\text { Winkel } \\
\text { des gesichsdreiecks } \\
\text { II ( } \angle \text { pr-n-ba) }\end{array}$ & 64.0 & - & 64.0 & 1 & - \\
\hline & $\begin{array}{l}\text { Winkel } \\
\text { des gesichsdreiecks } \\
\text { III ( } \angle n \text {-ba-pr) }\end{array}$ & 40.0 & - & 40.0 & 1 & - \\
\hline & Nasal bridge angle & 19.0 & 17.0 & 18.0 & 2 & 1.41 \\
\hline $8: 1$ & Cranial index & 75.64 & 74.73 & 75.19 & 2 & 0.64 \\
\hline $17: 1$ & Cranial length -height index & 74.79 & - & 74.79 & 1 & - \\
\hline $17: 8$ & Cranial height -breadth index & 98.86 & - & 98.86 & 1 & - \\
\hline $9: 8$ & Forehead breadth index & 69.7 & 66.33 & 68.02 & 2 & 2.38 \\
\hline $16: 7$ & Index of occipital foramen & 79.03 & - & 79.03 & 1 & - \\
\hline $40: 5$ & Gnathic index & 92.31 & - & 92.31 & 1 & - \\
\hline 48:17 рг & Vertical cranial index & 50.34 & - & 50.34 & 1 & - \\
\hline $48: 17 \mathrm{sd}$ & & 51.95 & - & 51.95 & 1 & - \\
\hline $48: 45$ рг & Upper facial index (K) & 50.34 & - & 50.34 & 1 & - \\
\hline $48: 45 \mathrm{sd}$ & & 51.92 & - & 51.92 & 1 & - \\
\hline 48:46 рг & Middle facial index (V) & 67.04 & - & 67.04 & 1 & - \\
\hline $48: 46 \mathrm{sd}$ & & 69.18 & - & 69.18 & 1 & - \\
\hline $54: 55$ & Nasal index & 52.38 & 54.36 & 53.37 & 2 & 1.40 \\
\hline $52: 51 \mathrm{~L}$ & Orbital index & 78.62 & - & 78.62 & 1 & 78.62 \\
\hline $52: 51 \mathrm{R}$ & & 73.56 & 78.65 & 76.11 & 2 & 3.60 \\
\hline 52:51a L & Orbital index & 84.24 & - & 84.24 & 1 & - \\
\hline 52:51a R & & 79.01 & 82.55 & 80.78 & 2 & 2.50 \\
\hline $54: 51 \mathrm{~L}$ & Nasal orbital index & 63.22 & - & 63.22 & 1 & - \\
\hline $54: 51 \mathrm{R}$ & & 63.22 & 64.49 & 63.86 & 2 & 0.90 \\
\hline 54:51a L & Nasal orbital index & 67.9 & - & 67.9 & 1 & - \\
\hline 54:51a R & & 67.73 & 67.69 & 67.71 & 2 & 0.03 \\
\hline SS:SC & Nasal base index & 20.0 & - & 20.0 & 1 & - \\
\hline $61: 60$ & Alveolar index & 123.6 & 125.58 & 124.59 & 2 & 1.40 \\
\hline 63:62 & palatal index & 80.85 & 90.61 & 85.73 & 2 & 6.90 \\
\hline $\begin{array}{l}\text { 45: } \\
(1+8) / 2\end{array}$ & Transverse cranial index & 81.57 & - & 81.57 & 1 & - \\
\hline
\end{tabular}


Table 2. Continued

\begin{tabular}{|l|l|l|l|l|l|l|}
\hline Martin No. & Measured Items & $\begin{array}{l}\text { Skull } \\
\mathbf{1}(\odot)\end{array}$ & $\begin{array}{l}\text { Skull } \\
\mathbf{2 (}()\end{array}$ & Average & Examples & $\begin{array}{l}\text { Standard } \\
\text { error }\end{array}$ \\
\hline $\begin{array}{l}17: \\
(1+8) / 2\end{array}$ & High level index & 85.15 & - & 85.15 & 1 & - \\
\hline
\end{tabular}

Table 3. The Dij values used for comparison of the Huoshiliang group to nine ancient groups (female).

\begin{tabular}{|c|c|c|c|c|c|c|c|c|c|}
\hline & Xicun & Qucun & Pengpu & Shaolingyuan & Hedang & $\begin{array}{l}\text { Liuwan } \\
\text { unite }\end{array}$ & $\begin{array}{l}\text { Shangsunjiazhai } \\
\text { (Han) }\end{array}$ & $\begin{array}{l}\text { Shangsunjiazhai } \\
\text { (Kayue) }\end{array}$ & Lijiashan \\
\hline HSL & 18.23 & 13.06 & 14.89 & 15.15 & 27.43 & 10.31 & 15.31 & 13.78 & 14.06 \\
\hline
\end{tabular}
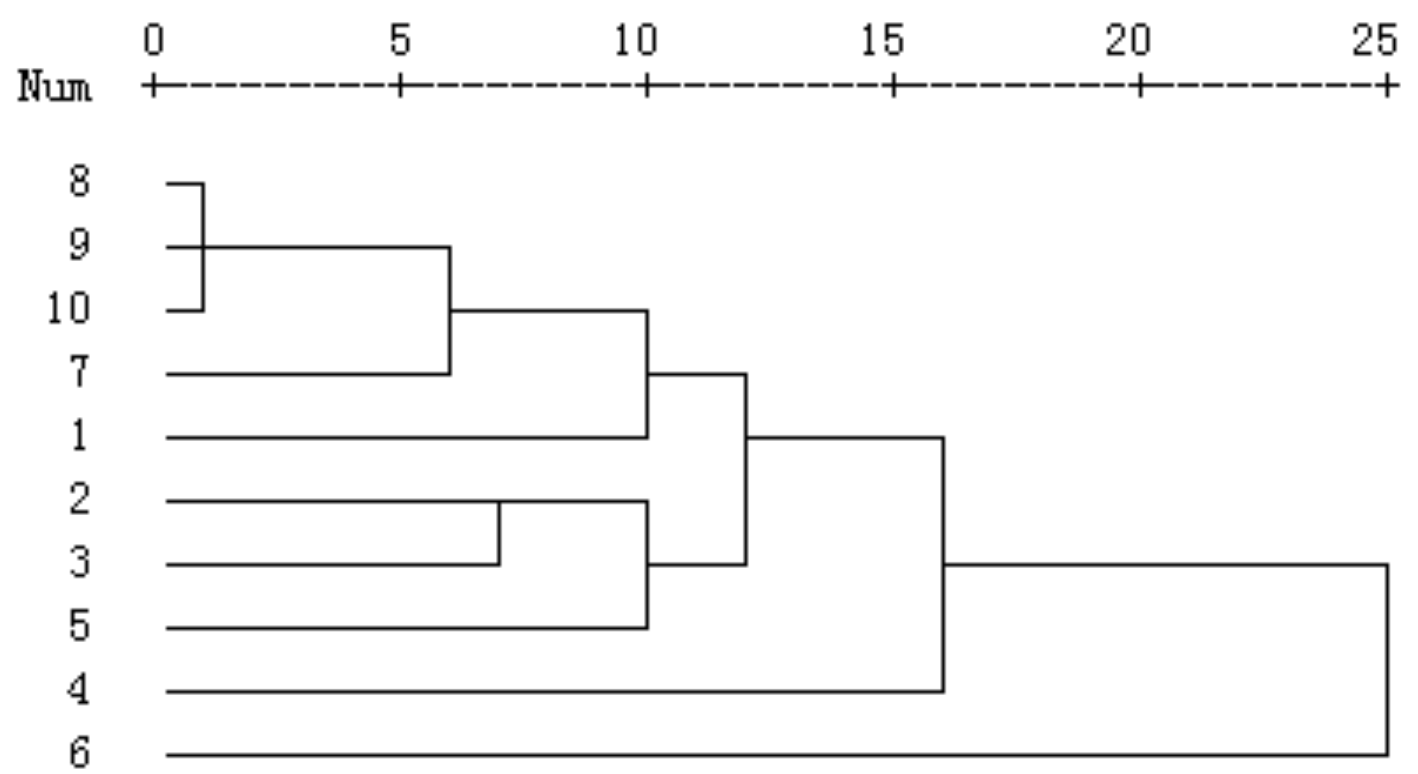

Figure 4. Hierarchical analysis map between the Huoshiliang skulls and other groups. Where $1=$ Huoshiliang; $2=$ Xicun; $3=$ Qucun; 4 = Pengpu; 5 = Shaolingyuan; 6 = Hedang; 7 = United Liuwan group; 8 = Shangsunjiazhai (Han); 9 = Shangsunjiazhai (Kayue); and $10=$ Lijiashan.

from the bone samples was sufficiently preserved for reliable dating. The samples also exhibited an acceptable level of nitrogen in the whole bone sample. Measuring the percentage of nitrogen of the whole bone allows us to estimate the quantity of collagen present before chemical treatment commences. For nitrogen, this usually ranges from approximately $4 \%$ in a fresh bone to below $0.2 \%$ in a poorly preserved bone (Tisnérat-Laborde et al. 2003). The nitrogen levels of the bones (ca. 4\%) was acceptable, although the yield for OZL292 was surprisingly low. The small amount of collagen extracted from that bone appears not to be the result of poor preservation, as the percentage of nitrogen of the whole bone was of an acceptable value (4.1\%) and the C:N ratio (3.23) of the collagen was satisfactory. This unusual result is most likely explained by a loss of collagen during the pre-treatment steps. In general, the $\mathrm{C}: \mathrm{N}$ ratios of the collagen were within the acceptable range (ca. 3\%), indicating that the collagen preservation was acceptable for dating (see Deniro 1985) and contaminants had been effectively removed.

The skull ages and the sheep bone overlap in age in the $\pm 2 \sigma$ range (Table 4 shows the $\pm 1 \sigma$ values and $\pm 2 \sigma$ calibrated range values), which probably puts them all within an age range of 1700-2017 cal BC. The calibrated ages are based on Reimer et al. (2004). Other radiocarbon dates from the site have yet to be published and these are based on charcoal (five samples) and a charred wheat seed (one sample). These all have calibrated ages within the range 1733 to 2135 
$\mathrm{cal} \mathrm{BC}$ and the dates are therefore consistent within the site and the bone ages are consistent with these. The sheep bone sample has an indistinguishable radiocarbon age from the human skulls, suggesting they were contemporaneous.

The $\delta^{13} \mathrm{C}$ values of the human skulls are about the same, but they are low negative values (ca. -8 to $-9 \%$ ). The sheep bone had a value of ca. $-18 \%$.

The seed analysis was based on 13,472 identified seeds (Table 5). The relative ease of finding cereal seeds suggests that crops were a staple part of the diet and people at the site were farmers. The seeds were dominated by broomcorn and foxtail millet types, with the latter declining in proportion above about $60 \mathrm{~cm}$ depth, when wheat and oat make an increasing contribution. Broomcorn millet is the dominant seed type in the upper layers, suggesting this was by far the dominant local crop, but an increase in crop diversity in the upper layers is suggested by the seed numbers.

\section{Discussion}

Table 4. Bone protein, $\delta 13 C, \delta 15 \mathrm{~N}$ and radiocarbon results. Calibrated ages are from Reimer et al. (2004).

\begin{tabular}{|c|c|c|c|c|c|c|c|c|}
\hline $\begin{array}{l}\text { Sample } \\
\text { name }\end{array}$ & $\begin{array}{l}\text { Bone } \\
\text { protein } \\
\text { yield }(\%)\end{array}$ & $\begin{array}{l}\text { Whole } \\
\text { bone N } \\
(\%)\end{array}$ & $\begin{array}{l}\delta^{13} \mathrm{C} \\
(\% / 00) \\
\text { graphite } \\
\text { collagen }\end{array}$ & $\begin{array}{l}\delta^{15} \mathrm{~N} \\
(\% / 00\end{array}$ & $\begin{array}{l}\text { Collagen } \\
\text { C:N ratio }\end{array}$ & $\begin{array}{l}\text { AMS date } \\
\text { number }\end{array}$ & Age BP & $\begin{array}{l}\text { Calibrated } \\
\text { age (BC) } \\
\pm 2 \sigma\end{array}$ \\
\hline HSG-01 & 0.5 & 4.22 & $\begin{array}{l}-8.2 \pm 0.1 \\
-8.71\end{array}$ & 6.1 & 3.19 & OZL 292 & $3515 \pm 45$ & $1955-1737$ \\
\hline HSG-02 & 4.1 & 4.1 & $\begin{array}{l}-9.0 \pm 0.1 \\
-8.86\end{array}$ & 9.8 & 3.23 & OZL 293 & $3590 \pm 45$ & 2124-1995 \\
\hline HSG-03 & 6.5 & 3.93 & $\begin{array}{l}-17.5 \pm 0.1 \\
-18.51\end{array}$ & 11.8 & 3.20 & OZL 294 & $3515 \pm 40$ & $1946-1776$ \\
\hline
\end{tabular}

Table 5. Distribution of seed types with depth at Huoshiliang.

\begin{tabular}{|c|c|c|c|c|c|c|c|}
\hline $\begin{array}{l}\text { Sample } \\
\text { depth (cm) }\end{array}$ & $\begin{array}{l}\text { Panicum } \\
\text { miliaceum } \\
\text { Broomcorn } \\
\text { millet }\end{array}$ & $\begin{array}{l}\text { Setaria } \\
\text { italica } \\
\text { Foxtail } \\
\text { millet }\end{array}$ & $\begin{array}{l}\text { Iriticum } \\
\text { Wheat }\end{array}$ & $\begin{array}{l}\text { Avena } \\
\text { sativa 0at }\end{array}$ & $\begin{array}{l}\text { Hordeum } \\
\text { vulgare } \\
\text { Barley }\end{array}$ & Other & Total seeds \\
\hline $0-20$ & 95.74 & 2.13 & 1.49 & 0.11 & 0 & 0.54 & 900 \\
\hline $20-40$ & 90.03 & 9.47 & 0.41 & 0.01 & 0 & 0.09 & 10973 \\
\hline $40-60$ & 92.08 & 5.87 & 1.76 & 0.07 & 0 & 1.72 & 1256 \\
\hline $60-80$ & 76.21 & 18.97 & 2.41 & 0 & 0.69 & 0 & 221 \\
\hline $80-100$ & 73.24 & 26.76 & 0 & 0 & 0 & 0 & 52 \\
\hline $100-120$ & 77.61 & 22.39 & 0 & 0 & 0 & 0 & 52 \\
\hline $120-140$ & 72.22 & 27.08 & 0 & 0 & 0 & 0 & 13 \\
\hline $140-160$ & 100.00 & 0 & 0 & 0 & 0 & 0 & 5 \\
\hline
\end{tabular}

The correspondence of the radiocarbon ages of the skulls, sheep bone and other materials from the site indicate that Huoshiliang was occupied by East Asian people between about $1860 \mathrm{BC}$ and $2020 \mathrm{BC}$. The skull dates are the first definitive early ages of Mongoloid people in this part of Central Asia. Earlier people from the region were possibly Caucasoid (e.g. Barber 1999), but since the remains analysed in this study are from a sample of two, it remains to be demonstrated whether the site was wholly occupied by Mongoloid people, whether there was mixed occupation, or whether there was merely the opportunity for exchange.

Elsewhere, we have published evidence of bronze technology (Dodson et al. 2009) and we have also noted that wheat, barley and oats at Huoshiliang are among the oldest in China 
( $\mathrm{Li}$ et al. 2007). It is probable that this mix arose from western Asia and is thus indicative of at least strong east-west interaction by around $2000 \mathrm{BC}$. The seed evidence shows that millets, the quintessentially north China and Yellow River valley crops, dominated agriculture at Huoshiliang.

Stable isotope analyses on bone can reveal much about diet and living conditions of individuals (Larsen 1998). In this case, the human bones had low negative $\delta^{13} \mathrm{C}$ values, which indicates that $\mathrm{C} 4$ plants, and possibly protein from animals which fed on $\mathrm{C} 4$ plants, were the mainstay of the diet. There has been no systematic study of the abundant animal bone at the site, although sheep bone fragments are relatively common. However, the human ${ }^{15} \mathrm{~N}$ values $(6-$ $10 \% 0$ ) are low and suggest that very little animal protein was consumed. The sheep value may be inflated due to fertilising pastures or manuring. Millet agriculture originated in the Yellow River valley of China from about $8000 \mathrm{BP}$; these are $\mathrm{C} 4$ plants, while wheat, oats and barley are $\mathrm{C} 3$ plants. We surmise that millet was the underpinning mainstay of the human food chain at Huoshiliang around $2000 \mathrm{BC}$. The sheep bone had a more negative $\delta^{13} \mathrm{C}$ value, suggesting part of its diet included C3 plants.

Several other studies in the Yellow and Wei river systems of northern and northeastern China, where millet agriculture originated, have measured similar $\delta^{13} \mathrm{C}$ values in human bone samples and concluded that millets must have been the mainstay of the food chain to humans (Pechenkina et al. 2005; Hu et al. 2008). Barton et al. (2009) recently argued that the domestication of dogs and pigs in northern China was accompanied by a shift to less negative $\delta^{13} \mathrm{C}$ values, which were associated with broomcorn and foxtail millet forming part of their diet.

The sheep bone from Huoshiliang has a more negative $\delta^{13} \mathrm{C}$ value, but one that is less negative than $\mathrm{C} 3$ plants in general, suggesting its diet was a mix of $\mathrm{C} 3$ and $\mathrm{C} 4$ plant foods. Perhaps sheep protein was not a large part of the Huoshiliang women's diet.

Skull No. 1 showed periodontitis. More than $50 \%$ of the tooth roots were exposed. For the left top jaw, P1, P2, M1 show abscess, and some corroded holes in the cheek side had diameters of $3.8 \mathrm{~mm}, 4.5 \mathrm{~mm}$ and $4.0 \mathrm{~mm}$ respectively. In Skull No. 2, all teeth had fallen out in the upper jaw. The alveolar had atrophied and closed completely. Both skulls thus show severe mouth disease and poor teeth health. This may be evidence of a narrow diet based on millet. Larsen argued some time ago (Larsen 1998) that the agricultural transition from hunter-gather society was probably associated with greater sedentism, narrower diet and a proneness to poor dental health and even earlier death.

\section{Conclusion}

The morphological characteristics of the two skulls from Huoshiliang show they are female and are representatives of the East Asia type of the Mongoloid race. The cluster analysis shows that the skull morphologies are similar to those of groups that were in China from the Neolithic to Han Dynasty times. The individuals and the archaeological site in which they were found have an age between $1860 \mathrm{BC}$ and $2020 \mathrm{BC}$, and evidence of pottery, bronze and agriculture suggests they were part of a complex society with strong technological links to both western and eastern Asia. While the range of crops became more complex with the introduction of wheat, oats and barley, millets remain the dominant food plant, and this is reflected in the stable-isotope data obtained from the bones. The two individuals may have lived before a diversification of additional crops appeared at the site. The lack of animal protein and reliance on millet consumption may have contributed to poor oral health. 


\section{Acknowledgements}

We thank the Chinese Academy of Sciences and the Australian Nuclear Science and Technology Organisation for support of the project. Ms Hu Songmei (Archaeological Institute of Shaanxi Province, Xian) kindly identified the sheep-bone sample.

\section{References}

Barber, E.W. 1999. The Mummies of Ürümchi. London: W.W. Norton Press.

Barton, L., Newsome, S.D., Chen, F.H., Wang, H., Guilderson, T.P. and Bettinger, R.L. 2009. Agricultural origins and the isotopic identity of domestication in northern China. Proceedings of the National Academy of Sciences 106:523-5528.

Bohlke, J.K. and Coplen, T.B. 1995. Interlaboratory comparison of reference materials for nitrogen isotope ratio measurements, taken from an IAEA Technical report, Reference and intercomparison materials for stable isotopes of light elements. IAEA-TECHDOC825. September 1995.

Bronk Ramsey, C., Higham, T., Bowles, A. and Hedges, R. 2004. Improvements to the Pretreatment of Bone at Oxford. Radiocarbon 46:155-163.

Brown T.A., Nelson, D.E., Vogel, J.S. and Southon, J.R. 1988. Improved Collagen Extraction by Modified Longin Method. Radiocarbon 30:171-177.

Chengwen, G., and Yoshinori, Y. 2002. Study on the Bronze Culture of the Yangtze River Valley. Beijing: Science Press.

Deniro, M.J. 1985. Postmortem preservation and alteration of in vivo bone collagen isotope ratios in relation to palaeodietary reconstruction. Nature 317:806-809.

Dodson,J.,Li,X.Q.,Zhou,X.Y. and Levchenko, V.2009. Bronze in two Holocene archaeological sites in Gansu, NW China. Quaternary Research 72:309-314.

Gonfiantini, R., Stichler, W. and Rozanski, K. 1995. Standards and intercomparison materials distributed by the International Atomic Energy Agency for stable isotope measurements, IAEA-TECDOC-825, pp.13-29.

Han, K.X., Tang, J.Z. and Zhang, F. 2005. The racio-anthropological study on ancient west-north area, China. Shanghai: Fudan University Press.

Higham, T.F.G., Jacobi, R.M. and Bronk Ramsey, C. 2006. AMS Radiocarbon Dating of Ancient Bone Using Ultrafiltration. Radiocarbon 48(2):179-195.

Hu, Y., Wang, S., Luan, F., Wang, C. and Richards, M.P.2008. Stable isotope analysis of humans from Xiaojingshan site: implications for understanding the origin of millet agriculture in China. Journal of Archaeological Science 35:2960-2965.

Hua, Q. Jacobsen, G.E., Zoppi, U., Lawson, E., Williams, A.A., Smith, A.M. and McMann, M.J. 2001. Progress in Radiocarbon Target Preparation at the ANTARES AMS Centre. Radiocarbon 43:275-282.

Larsen, C.S. 1998. Post-Pleistocene human evolution: bioarchaeology of the agricultural transition. 14th International Congress of Anthropological and Ethnological Sciences, Williamsburg, Virginia, July 26-August 1, 1998.

Le Clercq, M., van der Plicht, J. and Gröning, M. 2006. New 14C reference materials with activities of 15 and 50 pMC. Radiocarbon 40(1):295-297.

Li, X., Dodson, J., Zhou, X., Zhang, H. and Masutomoto, R. 2007. Early cultivated wheat and broadening of agriculture in Neolithic China. The Holocene 17:555-560.

Liu, L. 2004. The Chinese Neolithic: trajectories to early states. Cambridge: Cambridge University Press. 
Martin, R. 1928. Lehrbuch der Anthropologie in systematischer Darstellung mit besonderer Berücksichtigung der anthropologischen Methoden für Studierende, Ärzte und Forschungsreisende. Jena: Fischer.

Pechenkina,E.A.,Ambrose, S.H.,Xiaolin,M.and Benfer Jr,R.A.2005. Reconstructing northern Chinese Neolithic subsistence practices by isotopic analysis. Journal of Archaeological Science 32:1176-1189.

Reimer, P.J. and 27 others. 2004. IntCal04 terrestrial radiocarbon age calibration, 0-26 cal kyr BP. Radiocarbon 46:1029-1058.

Tan J., Han, Z. and Kang, F. 2005. The ancient residents of Northwest China ethnic studies. Shanghai: Fudan University Press.

Tao, S. 2001. Papers on the Bronze Age archaeology of northwest China. Beijing: Science Press.

Tisnèrat-Laborde, N., Valladas, H., Kaltnecker, E. and Arnold, M. 2003. AMS Radiocarbon Dating of Bones at LSCE. Radiocarbon 45:409-419.

Underhill, A.P., Feinman, G.M., Nicholas, L.M., Fang, H., Luan, F., Yu, H.G. and Cai, F. 2008. Changes in regional settlement patterns and the development of complex societies in southeastern Shandong, China. Journal of Anthropological Archaeology 27:1-29. 